\title{
PROJEKTOWANIE I TECHNOLOGIA WYKONANIA ELEMENTÓW KOMPOZYTOWYCH O ZŁOŻONEJ GEOMETRII DO ZASTOSOWAŃ W BUDOWIE URZĄDZEŃ WYSOKOOBROTOWYCH
}

\author{
Katarzyna Kaczorowska, Michae Jakubowski \\ Politechnika Rzeszowska, Wydzial Budowy Maszyn i Lotnictwa, Rzeszów \\ e-mail: kaczorowskakatarzyna15@gmail.com; michal.jakubowski.96@gmail.com
}

\begin{abstract}
W pracy przedstawiono problematykę projektowania i opracowania technologii wykonania elementów kompozytowych o złożonej geometrii do zastosowań w budowie urządzeń wysokoobrotowych na podstawie wykonania zespołu chłodzacego ogniwo paliwowe motoszybowca AOS-H2. Aby użycie laminatu węglowego i szklanego w tego typu konstrukcji było uzasadnione (zważywszy na stosunkowo nieduże maksymalne wymiary średnicowe zespołu wynoszące $200 \mathrm{~mm}$ ), opisano specjalne techniki pracy z materiałem kompozytowym. Zaprezentowano uniwersalny projekt samego wentylatora jako elementu wysokoobrotowego, dzielącego jego budowę na elementy możliwe do wykonania w technologii kompozytowej w stosunkowo niedługim czasie i niewielkim kosztem przy zachowaniu niskiej masy i niezawodności gotowego wyrobu. W artykule, między innymi, przedstawiono przebieg projektowania form w materiale typu ProLab o niewielkiej gęstości z zastosowaniem „murków ochronnych” na krawędziach narażonych na uszkodzenia podczas obróbki polepszającej jakość powierzchni i ich podział w płaszczyźnie równoległej do kierunku odformowania, kompleksowy proces obróbki łopatek węglowych z zastosowaniem narzędzi wykonanych technikami przyrostowymi, jak i technologię montażu poszczególnych elementów składowych. Dzięki zastosowaniu specjalnych technik projektowania i wykonania, jakość gotowego wyrobu uzasadniła użycie materiałów kompozytowych w niewielkich konstrukcjach wysokoobrotowych.
\end{abstract}

\section{Wstęp}

Artykuł stanowi opis procesu projektowania, tworzenia technologii wykonania kompozytowego wentylatora będącego częścią większego projektu, jakim była budowa dwustopniowej turbiny chłodzącej ogniwo paliwowe motoszybowca AOS-H2, za którego zaprojektowanie i wytworzenie odpowiedzialni byli autorzy niniejszej pracy. Powszechna opinia o niemal nieograniczonej możliwości uzyskiwania dowolnych kształtów dla elementów wykonywanych z kompozytów polimerowych wydała się nieobowiązująca w przypadku stosunkowo niewielkich konstrukcji wysokoobrotowych (generujących przepływ powietrza poprzez zastosowanie łopatek), dla których dbałość o jakość gotowego wyrobu jest szczególnie istotna z punktu widzenia zapewnienia wytrzymałości urządzenia obciążonego silnie aerodynamicznie, siłami odśrodkowymi czy drganiami związanymi z nieuniknionym występowaniem mimośrodu. Wcześniej podjęte próby wykonania elementów typu kompozytowy wentylator (o wymiarach średnicowych nie przekraczających $200 \mathrm{~mm}$ ) bez zmiany, adaptacji czy tworzenia nowych metod produkcyjnych okazały się nieskuteczne, dlatego zdecydowano się na zakwalifikowanie tego typu elementów jako konstrukcji, dla których sposoby budowy, montażu czy projektowania nie są jeszcze dostępne i ujęte w literaturze czy innych źródłach wiedzy. Taki wniosek skłonił konstruktorów do przemyślenia problematyki projektu wentylatora, technologii wykonania i sposobu jego montażu, zakładając zaadaptowanie oraz tworzenie nowych sposobów wytwórczych części laminatowych, czy projekt i wykonane narzędzi specjalnych służących na przykład do obróbki półfabrykatów, a także hybrydyzację technik znanych, chociażby takich jak laminowanie z użyciem worka próżniowego i metoda stempla, ale zastosowanych wspólnie w jednym procesie wykonawczym danego elementu składowego. 
Artykuł można uznać za źródło wiedzy czy instrukcję projektowania i wykonania kompozytowych wentylatorów stosowanych jako elementy generujące przepływ powietrza turbin chłodzących o maksymalnych wymiarach średnicowych z zakresu 190-250 mm i długości łopatek z przedziału 40-70 mm napędzanych silnikami elektrycznymi typu „outrunner”.

\section{Projekt wentylatora}

Wentylator, ze względu na charakter obciążenia i warunki pracy elementu, projektowano jako najważniejszą i najbardziej odpowiedzialną część zespołu chłodzącego. Na wczesnym etapie projektowym zakładającym analizę wytrzymałościową zauważono, że ilość materiału, a precyzyjniej uzyskane pole przekroju poprzecznego wszystkich odpowiedzialnych elementów konstrukcji, umożliwiające pracę z jakąś częścią (na przykład obróbkę półfabrykatu łopatki) znacznie przewyższa liczbę warstw tkaniny węglowej zapewniającą wytrzymałość na działające siły i stan obciążenia. Oznacza to, że dla tak małych konstrukcji, wykonanych z dobrej jakości tkanin i przy wysokiej jakości wyrobu, należy zapewnić ilość materiału nie tyle wynikającą z warunku wytrzymałościowego, co umożliwiającą pracę z gotowym elementem na etapie montażu czy eksploatacji. Przykładowo, łopatki wentylatora wykonane przy powierzchni pola przekroju zapewniającej wytrzymałość ze względu na stan obciążenia mogą być narażone na uszkodzenie (nie widoczne gołym okiem) już przy odformowaniu, ponieważ siły działające w procesach produkcyjnych często będą większe niż te występujące $\mathrm{w}$ trakcie eksploatacji. Jednym z istotniejszych powodów takiego stanu rzeczy jest niska masa wyrobu, w związku z czym występują niewielkie siły odśrodkowe, co wyglądałoby diametralnie inaczej w przypadku działania takiego samego geometrycznie elementu, ale na przykład frezowanego metodami CNC z metalu (aluminium). Swoista optymalizacja takich części powinna być ukierunkowana na zapewnienie możliwości użytkowych gotowego detalu, równocześnie zapewniając niską masę czy wytrzymałość na działające siły.

Podczas fazy koncepcyjnej projektu wentylatora bardzo szybko okazało się, że jego konstrukcję należy podzielić na elementy składowe, których geometria charakteryzuje się małym skomplikowaniem na etapie półfabrykatu - niekoniecznie jako gotowego elementu. Ma to związek niejako z ograniczeniem technologicznym frezowania form (zważywszy na minimalizację czasu na ich wykonanie), ale głównie z powodu konieczności zapewnienia dobrego i równomiernego docisku przesączonej tkaniny węglowej między formą a workiem próżniowym czy między formą a stemplem. Na zdjęciu (rys. 1) widać przykład próbki, dla której docisk nie został zapewniony w sposób wystarczający, z powodu czego żywica niejako wyprzedziła tkaninę. Oznacza to, że zewnętrzna warstwa próbki składa się jedynie z osnowy, nie stanowiąc kompozytu z materiałem (strefa A), a także - co najważniejsze - wyraźnie widać pęcherze (strefa B) świadczące o braku styku laminatu z formą. Powodem takiego stanu jest zbyt gwałtowna zmiana geometrii materiału w strefach wad lub niedostosowanie technologii do wykonania elementu.

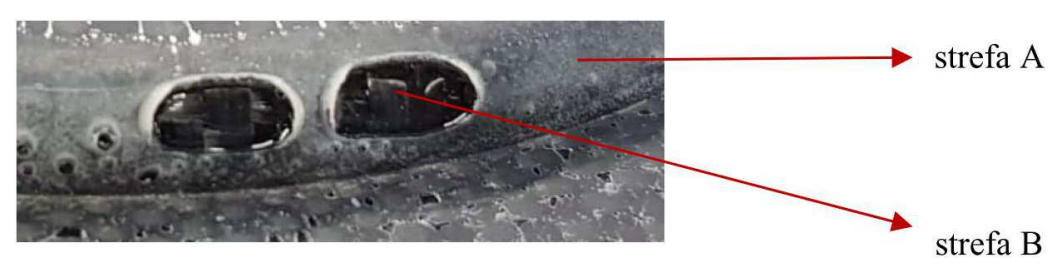

Rys. 1. Efekt niewystarczającego docisku na złożonej geometrii

Jak dowodzi powyższe, geometria poszczególnego elementu musi być mało skomplikowana, więc niemożliwe jest wykonanie wentylatora jako monolitu w jednym procesie laminowania. Próbowały tego dokonać poprzednie zespoły, ale części ulegały zniszczeniu już na etapie odformowania. Konstrukcję należy podzielić na elementy wykonalne o bardzo wysokiej jakości produktu, 
a następnie poddać je specjalnym metodom obróbki, nadając im finalny kształt czy właściwości, planując równolegle technologię ich montażu.

\subsection{Podział konstrukcji i wykonanie modeli}

Doboru podziału konstrukcji na poszczególne elementy składowe dokonywano, bazując na modelach 3D generowanych w środowisku Catia, składając je następnie w celu analizy ich trafności ze względu na możliwie najlepszą jakość wykonania. Ostateczna koncepcja zakładała podział wirnika na dwie tarcze, przednią (rys. 2a) i tylną (rys. 2b) oraz łopatki (rys. 3) jako oddzielne części. Uzyskane geometrie nie charakteryzują się złożonością kształtów i są możliwe do wylaminowania w bardzo wysokiej jakości przy odpowiednim zaprojektowaniu technologii wykonania i obróbki. Konstrukcja łopatek zakłada ich montaż do tarcz w sposób niejako klasyczny z punktu widzenia konstrukcji wirnikowych stosowanych obecnie w lotnictwie, ale niespotykany w konstrukcjach kompozytowych o podobnej skali wymiarowej. Mowa tu o montażu za pomocą połączenia zamkowego, dostosowanego do możliwości materiałowych i wykończeniowych. Kształt tarcz został zaprojektowany ze szczególną uwagą poświęconą na minimalizację zbędnych krzywizn, zapewniając wysoką jakość wyrobu w okolicach koniecznych zagięć kompozytu. Wklęsłość tarczy tylnej przewiduje wypukłość silnika, efektem czego jest zmniejszenie wymiarów podłużnych zespołu chłodzącego jako całości.
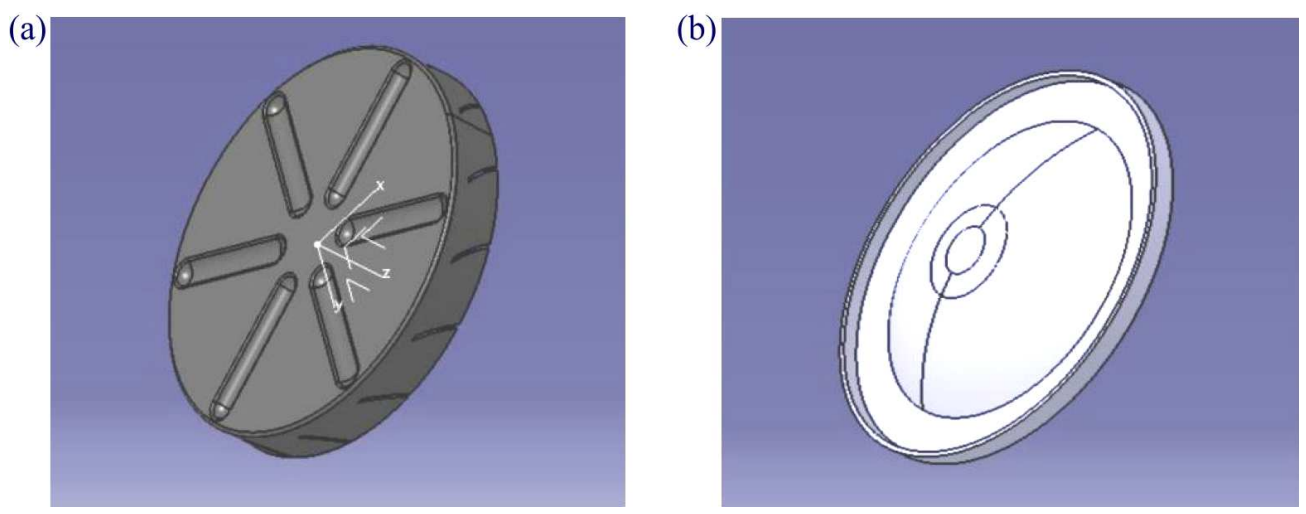

Rys. 2. Tarcze wentylatora: (a) przednia, (b) tylna

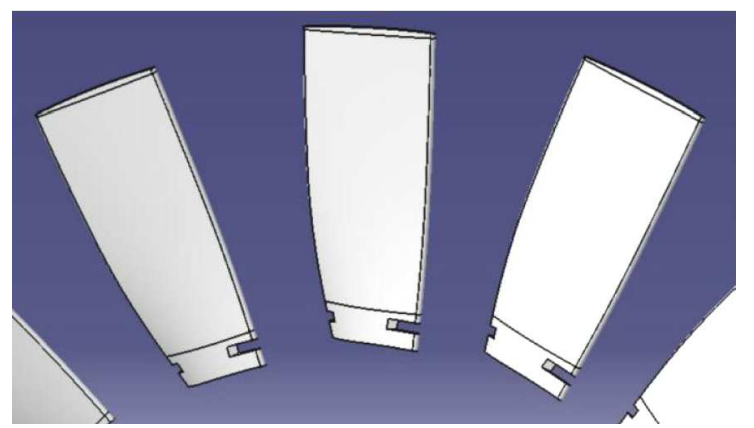

Rys. 3. Łopatki wentylatora

Złożenie elementów składowych pokazują rysunki 4a i 4b.

Zarówno rowki pod łopatki w tarczy przedniej, jak i zamek samej łopatki nie występują na etapie półfabrykatów po procesie odformowania. Elementy te muszą zostać poddane specjalnej obróbce przy użyciu narzędzi zaprojektowanych i wykonanych konkretnie pod daną fazę wykończeniową. Taki sposób projektowania wymagał opracowywania technologii wykonania elementu na etapie tworzenia jego modelu, a nie dostosowywania sposobu wyrobu detalu dla istniejącego 
(a)

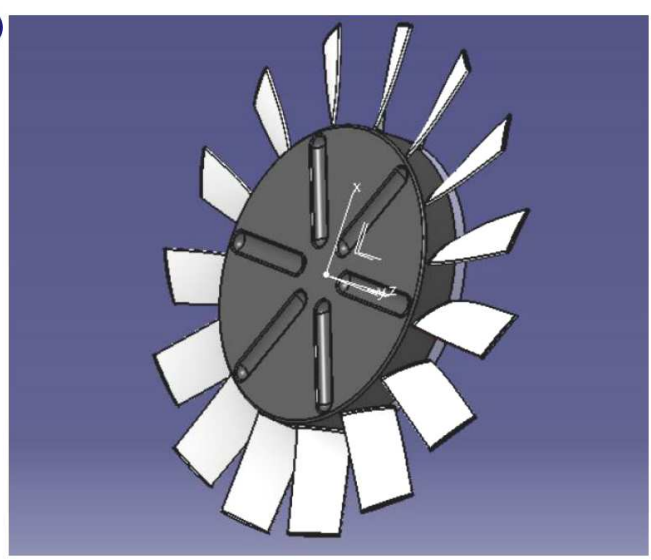

(b)

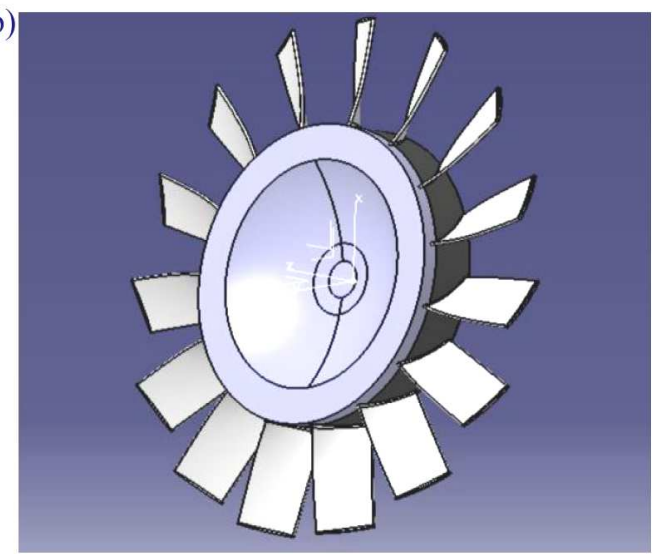

Rys. 4. Złożenie wentylatora. Widoczne: (a) tarcza przednia, (b) tarcza tylna

projektu części (dokładny opis procesu wykonania w dalszej części artykułu), dlatego równolegle z projektem elementów stworzono modele narzędzi obróbkowych i wykończeniowych. Przewidziano użycie i sposób wykonania poniżej opisanych narzędzi.

- Korona wzornikowa (rys. 5a) - jest to narzędzie projektowane w taki sposób, aby możliwe było umieszczenie półfabrykatu tarczy przedniej we wnętrzu korony (rys. 5b) i prowadzenie piły włosowej po odpowiedniej ścieżce w celu precyzyjnego nacięcia na tarczy przedniej wentylatora rowków pod łopatki. Fakt użycia tego typu narzędzia zapewnia mało skomplikowaną geometrię tarczy przedniej na etapie półfabrykatu i podczas laminowania, a sama operacja wycięcia rowków nie jest trudna do wykonania dzięki użyciu właśnie korony wzornikowej. Finalny kształt elementu można uznać za złożony, ale proces produkcyjny podzielony na etapy nadające rozsądne zmiany kształtu części kompozytowej wraz z kolejną operacją, umożliwia jej wykonanie. Korona wzornikowa jest jedynym narzędziem koniecznym do wykonania tej części metodą CNC z właściwie dowolnego stopu metalu (stali lub aluminium) w celu zapewnienia możliwości jej wielokrotnego użytku (zespół chłodzący jako całość jest dwustopniowy). Grubość ścieżek musi przekraczać $3 \mathrm{~mm}$, aby możliwe było odpowiednie napięcie i uregulowanie kształtu piły włosowej (dokładniej omówione w rozdziale 3.1). Szczyt korony, w celu zapewnienia odpowiedniego wcięcia narzędzia tnącego, powinien przewyższać wysokość tarczy o co najmniej $2 \mathrm{~mm}$.

(a)

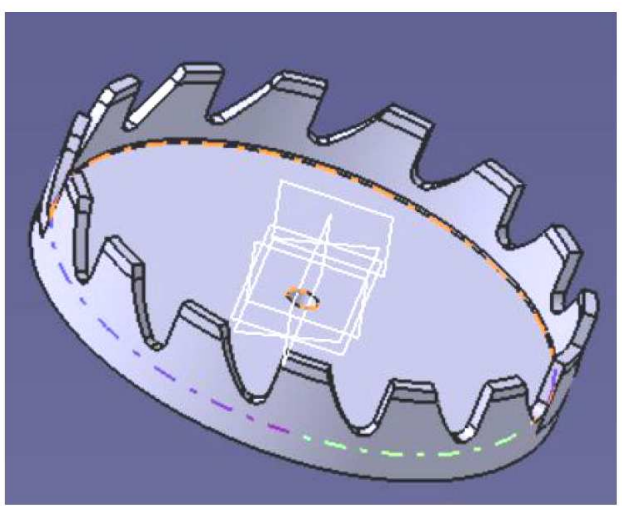

(b)

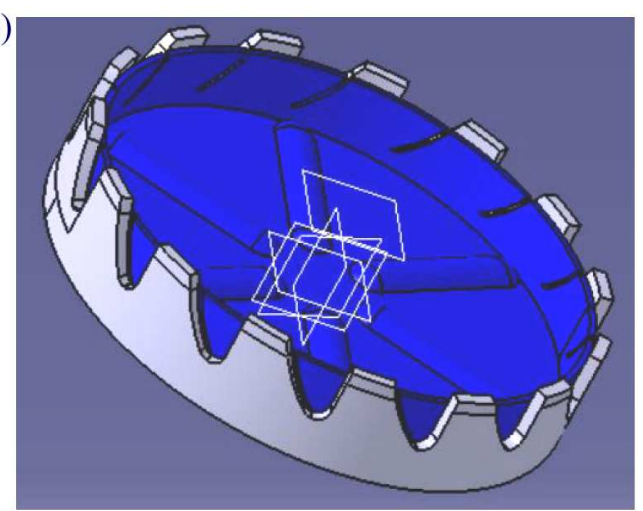

Rys. 5. (a) Model korony wzornikowej, (b) model korony wzornikowej z umieszczoną wewnątrz tarczą przednią

- Kształtowniki łopatek (rys. 6) - to narzędzia umożliwiające nadanie finalnego kształtu łopatkom wentylatora, dzięki którym półfabrykat staje się użytkową częścią. Podobnie jak w przypadku tarczy przedniej, technologia wykonania łopatki zapewnia małą wymaganą 
złożoność geometryczną półfabrykatu, jednak dzięki zastosowaniu późniejszych operacji obróbkowych stopniowo zwiększa się użyteczność elementu. Narzędzia tego typu najlepiej jest wykonywać metodą druku 3D ze względu na skomplikowany kształt i fakt występowania kanałów o zmiennym polu przekroju służących do nacinania zamków w łopatkach. Same kanały zaprojektowano w taki sposób, że niejako prowadzą one narzędzie skrawające, dzięki czemu wykonywanie rowków w łopatkach jest precyzyjne i powtarzalne. Użycie kształtownika zakłada umieszczenie półfabrykatu łopatki między dwiema częściami narzędzia, zabezpieczenie ruchu półfabrykatu względem kształtownika przy użyciu śrub, obrobienie krawędzi bocznych łopatki papierem ściernym i nacięcie rowków. Kształtownik wykonany z filamentu typu PETG, z wypełnieniem od 90\% do 100\%, umożliwia wykończenie od 10 do 15 łopatek wentylatora z zachowaniem wysokiej zgodności wymiarowej części rzeczywistej względem jej modelu 3D.

(a)

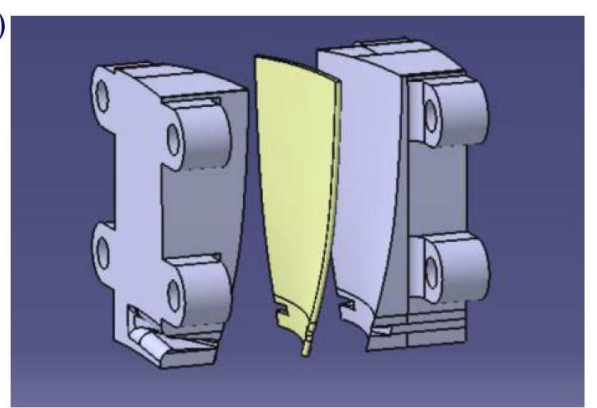

(b)

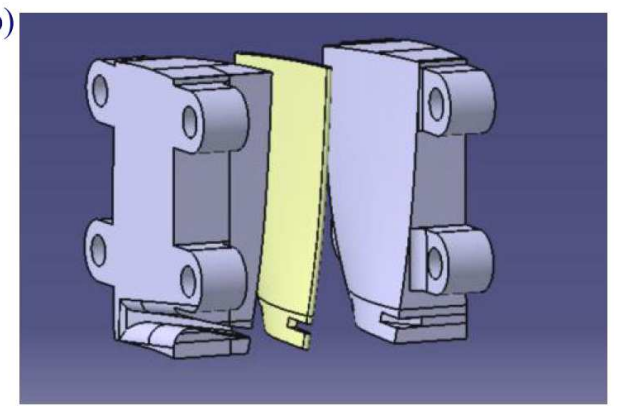

Rys. 6. Kształtowniki łopatek (widok A i B)

Na etapie projektu wentylatora przewidziano wszelkie trudności technologiczne, dostosowując kształt części do możliwości wytwórczych, wychodząc naprzeciw ograniczeniom materiałowym, projektując równocześnie zarówno elementy składowe jak i narzędzia służące do ich obróbki. Sama koncepcja podziału wentylatora na 3 główne elementy, przy zastosowaniu połączenia zamkowego łopatek, umożliwia precyzyjny montaż przy użyciu niewielkiej ilości kleju, nadając gotowemu wentylatorowi właściwości monolitu.

\subsection{Projekt form}

Korzystając z wykonanych w programie Catia modeli poszczególnych składowych wentylatora, należało wykonać projekty form. Założono wykonanie ich w materiale typu ProLab o niewielkiej gęstości przy użyciu obrabiarki CNC. Planując projekt zarówno samego wentylatora jak i form, należało podzielić elementy na te wykonywane metodac próżniową oraz metodą z użyciem docisku, tzw. stempla. Po dokładnej analizie dostępnych środków oraz biorąc pod uwagę fakt ograniczonego czasu na przeprowadzenie całości projektu, tarcze wykonano metodą hybrydową zakładającą laminowanie tych elementów w próżni z równoczesnym użyciem uniwersalnego stempla w postaci tulei dociskowej wykonanej technologią przyrostową (rys. 7). Tarcze przednia i tylna mają kąt prosty lub zaokrąglenie o niewielkim promieniu, dlatego narzędzie to zaprojektowano tak, aby z jednej strony posiadało właśnie kąt prosty, a z drugiej zaokrąglenie o promieniu R1,5. Dzięki technologii druku 3D możliwe było skrócenie czasu przygotowania stempla, a wykonanie go w sposób wielofunkcyjny ograniczyło koszty i zużycie materiału.

Zastosowanie metody hybrydowej zapobiega pojawieniom się ewentualnych nieciągłości materiału, a docisk zapewnia odpowiednie wykonanie tarczy z poprawnie wykończoną krawędzią zgięcia, eliminując miejsca o zbyt małym docisku, które mogłyby wystąpić w przypadku użycia wyłącznie technologii próżniowej, umożliwiając uzyskanie nawet jednomilimetrowych promieni zaokrąglenia. Dodatkowo zastosowano tutaj innowacyjne i autorskie rozwiązanie w postaci „murków ochronnych" (rys. 8) na krawędziach form, które szczególnie narażone są na uszkodzenia 


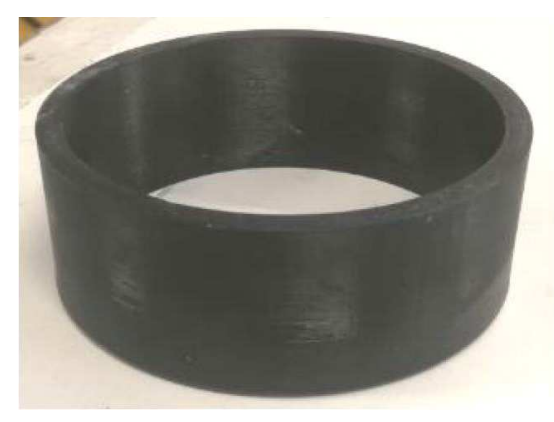

Rys. 7. Tuleja dociskowa

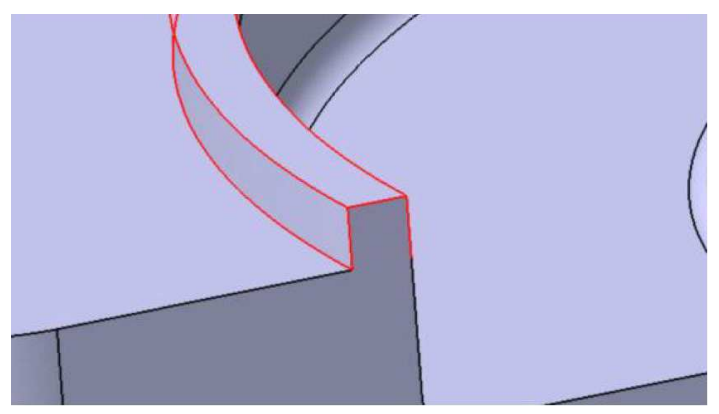

Rys. 8. Forma z zaznaczonym „murkiem ochronnym”

w czasie obróbki polepszającej jakość powierzchni przed laminowaniem, polegającej na szlifowaniu i polerowaniu, w wyniku której mogłoby nie dojść do styku tarczy przedniej z tylną podczas montażu. Optymalne wymiary murka to $2 \mathrm{~mm} \times 2 \mathrm{~mm}$. Gwarantują one wystarczającą trwałość elementu i zapobiegają jego kruszeniu podczas obróbki, ale również są łatwe do zeszlifowania po osiągnięciu oczekiwanej chropowatości powierzchni formy po obróbce.

Rozwiązując problem pojawienia się równoległych ścianek tarcz do kierunku odformowania (powszechnie uważny za błąd konstrukcyjny uniemożliwiający odformowanie półfabrykatu), opracowano specjalny podział form (rys. 9) w wybranej płaszczyźnie symetrii, pozwalający na uniknięcie ewentualnego ryzyka zniszczenia gotowego elementu bądź formy podczas próby oddzielenia ich od siebie. Rozwiązanie to wymagało wykonania połówek form w postaci puzzli, co zapewniło idealne dopasowanie poszczególnych części bez ryzyka wystąpienia braku koncentryczności. Praca przy użyciu takich form zakładała użycie niewielkiej ilości kleju cyjanoakrylowego, w celu uzyskania wytrzymałego połączenia między połówkami na czas obróbki, laminowania i utwardzania żywicy. Natomiast podczas procesu odformowania niewielka spoina zapewniła, że proces podziału był stosunkowo łatwy i nie wymagał użycia zbyt wielkiego nakładu siły.
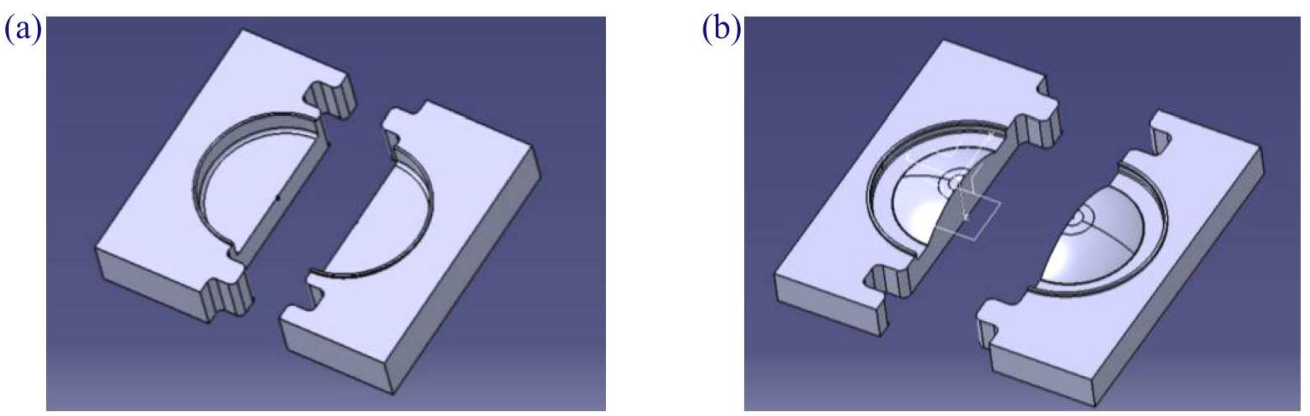

Rys. 9. Forma tarczy wentylatora: (a) przedniej, (b) tylnej 
Aby zminimalizować występujący w tarczowych konstrukcjach obrotowych mimośród niewyważenia, wykonano w formach niewielkie otwory $(\emptyset 1 \mathrm{~mm})$ jako znaczniki środków półfabrykatów. Dodatkowo sposób zaprojektowania tarcz zakładał umożliwienie wykonania otworów poprawiających wyważenie gotowego elementu.

Ze względu na stosunkowo niewielką grubość i potrzebę uzyskania dobrej jakości powierzchni łopatek wentylatora zdecydowano się na użycie do ich wykonania formy dociskowej w postaci stempla (rys. 10), poprzez który realizowano nacisk na materiał. W przypadku tego typu elementów niezwykle istotne jest zastosowanie odpowiedniej siły podczas utwardzania żywicy, aby finalny przekrój i sztywność gotowego wyrobu były zachowane, co z kolei decyduje o mechanizmie wywarcia odpowiedniej siły ściskającej (docisk zapewniony poprzez połączenie śrubowe, prasą, ściskami czy próżnię).

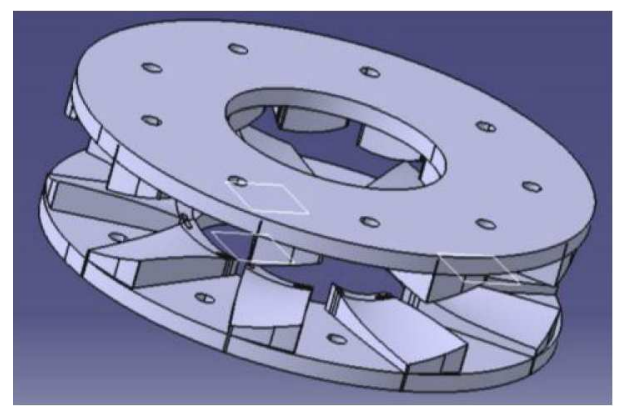

Rys. 10. Forma ze stemplem przeznaczona do wykonania łopatek wentylatora

Formę na łopatki zaprojektowano poprzez rozłożenie 11 powierzchni łopatek po okręgu. Liczba ta wyniknęła z przeprowadzonego eksperymentu, który wykazal, że podczas żelowania żywicy L285 połączonej z utwardzaczem H287 w proporcji 5:2 możliwe będzie wylaminowanie takiej właśnie ilości półfabrykatów łopatek. Zwracając uwagę na konieczność dokładnego wykonania łopatek, zdecydowano się na rozmieszczenie powierzchni do laminowania w taki sposób, aby była możliwa wstępna obróbka ich półfabrykatów jeszcze przed odformowaniem. W celu uzyskania połączenia koncentrycznego formy i stempla zastosowano połączenie śrubowe z użyciem śrub M6, a moment docisku uzyskano doświadczalnie, na podstawie wcześniej wykonanych prób z użyciem materiału węglowego, osiągając wartość zapewniająca odpowiednią grubość i sztywność gotowego wyrobu.

Jeszcze podczas etapu projektowania złożenia i form należało przewidzieć sposób montażu gotowych elementów składowych, w celu oceny liczby potrzebnych narzędzi i sprawdzianów. Po analizie uznano za konieczne wykonanie sprawdzianu montażowego (rys. 11a) służącego do kontroli odpowiedniego ułożenia montowanych łopatek względem tarczy, ze szczególnym zwróceniem uwagi na kąt natarcia i skręcenia. Element ten stosowano po wstępnym montażu łopatki do tarczy, kontrolując czy odpowiednie powierzchnie i krawędzie sprawdzianu pokrywają się z poszczególnymi powierzchniami i krawędziami montowanych części wentylatora.

Kołpak ze względu na charakter pracy zespołu chłodzącego (powietrze jest wysysane z komory ogniwa paliwowego) i fakt, że obraca się on z tą samą prędkością kątową co wentylator, podlega takim samym restrykcją projektowym jak reszta części wirujących. Forma powinna dać możliwość spiralnego ułożenia materiału w celu zapewnienia wytrzymałości na złożony stan naprężeń. Została ona zaprojektowana (rys. 11b) w sposób zakładający wykonywanie elementu w dwóch etapach. Niezbędne było wyfrezowanie powierzchni kołpaka podzielonej w płaszczyźnie symetrii tak, aby pierwszy etap laminowania wykonywać na dwóch osobnych połówkach, a następnie za pomocą dodatkowego materiału (typu textreme) przesączonego żywica skleić je, tworząc gotowy element. Na etapie projektu zaplanowano miejsce pod śruby służące do montażu z tarczą wentylatora. Forma jest dobrym przykładem zalet stosowalności „murków ochronnych” 
umożliwiających uzyskanie połączenia doczołowego dobrej jakości, w tym wypadku bardzo istotnego ze względu na sposób pracy gotowego wyrobu.
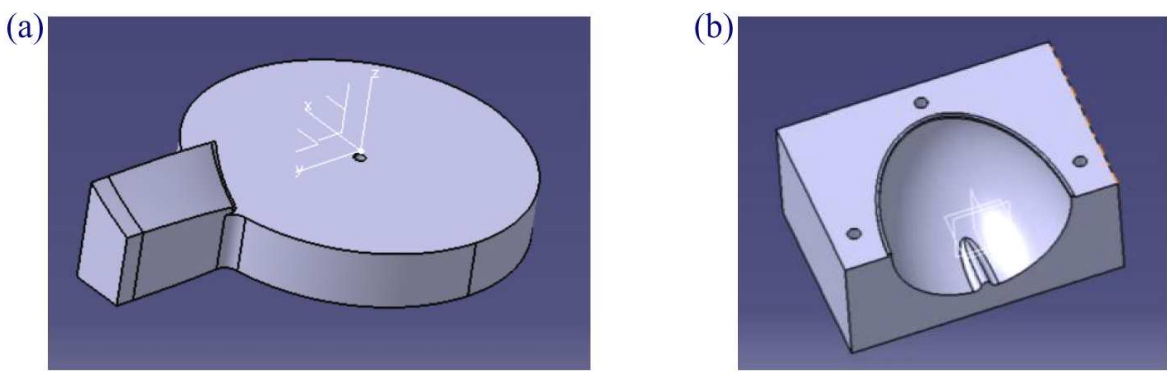

Rys. 11. (a) Sprawdzian montażowy, (b) połowa formy kołpaka

\section{Budowa wentylatora}

Przed przystąpieniem do wykonania wentylatora konieczne było przeprowadzenie prób materiałowych w celu określenia odpowiedniej liczby warstw danej tkaniny, aby zapewnić wynikającą z projektu grubość ścianek elementów. Całość procesu doświadczalnego nie mieści się w tematyce artykułu, więc nie będzie rozwijana. Warto jedynie zwrócić uwagę na rodzaje tkanin, jakie zostały ostatecznie zastosowane w procesie produkcyjnym samego wentylatora. Użyto następujące materiały:

- tkaninę węglową $200 \mathrm{~g} / \mathrm{m}^{2}$ o splocie typu twill (rys. 12a) - stosowana na wewnętrzne warstwy tarcz dzięki wysokim właściwością dopasowania się do nieregularnej geometrii z zachowaniem ciągłości struktury,

- tkaninę węglową $200 \mathrm{~g} / \mathrm{m}^{2}$ o splocie tradycyjnym (rys. 12b) - używana do budowy tarcz, współpracująca z tkaniną typu twill w elementach tarczowych,

- tkaninę węglową $80 \mathrm{~g} / \mathrm{m}^{2}$ o splocie tradycyjnym (rys. 12c) - używana do budowy łopatek,

- tkaninę jednokierunkową $60 \mathrm{~g} / \mathrm{m}^{2}$ - stosowana w łopatkach w celu polepszenia właściwości wytrzymałościowych.

(a)

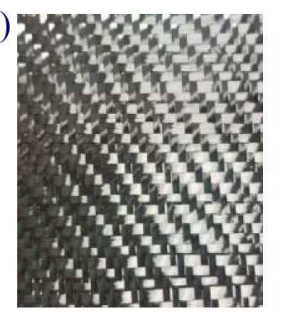

(b)

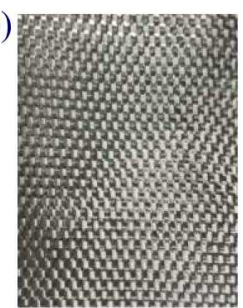

(c)

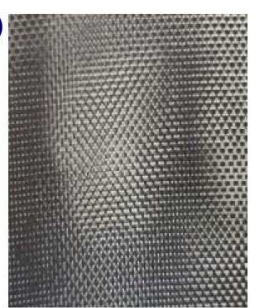

Rys. 12. Tkaniny: (a) o splocie typu twill $200 \mathrm{~g} / \mathrm{m}^{2}$, (b) węglowa $200 \mathrm{~g} / \mathrm{m}^{2}$, (c) węlowa $80 \mathrm{~g} / \mathrm{m}^{2}$

Przy doborze tkaniny na budowę łopatek z zastosowanym połączeniem zamkowym należało zwrócić szczególną uwagę na dobór materiału pod względem gęstości splotu, aby na ramieniu zamka znajdował się więcej niż jeden pełny kwadrat splotu. Z tego powodu dobrano włókno węglowe o zagęszczeniu około 64 kwadratów na centymetr kwadratowy. Zagęszczenie splotu nie jest często podawane przez producenta materiału, a w przypadku budowy tak niewielkich części kompozytowych nabiera dużego znaczenia ze względów wytrzymałościowych.

$\mathrm{Na}$ tym etapie należało także (w równoległym procesie doświadczalnym) dobrać odpowiednie wartości docisku materiału laminowanego, uzyskanego w worku próżniowym czy za pomocą stempla tak, aby zapewnić dobrą strukturę i sztywność laminatu. Warunki te należało odtworzyć podczas wykonywania elementu, aby zachować odpowiednie grubości ścianek, bowiem nie tylko liczba warstw samej tkaniny wpływa na końcowy wymiar produktu, lecz równie istotne znaczenie ma także siła ściskająca. 


\subsection{Wykonanie tarcz i łopatek wentylatora}

Budowę wentylatora rozpoczęto od laminowania tarcz, przedniej i tylnej. Wykonano je w sposób analogiczny, więc opisywane poszczególne procesy produkcyjne będą przedstawiane tylko raz. Na początku formy poddano obróbce powierzchni przez szlifowanie i polerowanie, a także usunięcie „murków ochronnych”. Procesy te, dzięki temu, że ProLab, z którego formy zostały wykonane, miał stosunkowo niedużą gęstość, nie stanowiły trudności technologicznych. Na przygotowaną do laminowania formę układano przesączone żywicą warstwy materiału w taki sposób, aby włókna kolejnych tkanin węglowych nie były równoległe. Zmiana kąta ułożenia miała za zadanie zwiększyć wytrzymałość gotowego wyrobu poprzez nadanie mu większej odporności na złożone stany naprężeń. Następnie formę z materiałem włożono do worka próżniowego i przy pomocy pompy uzyskano podciśnienie o wartości 900 mbar. W kolejnym kroku zastosowano tuleję dociskową (przyłożoną do materiału stroną z łukiem R1,5), którą obciążono odpowiednim, wynikającym z przeprowadzonego doświadczenia w próbach materiałowych, dociskiem. Elementy zostały umieszczone w próżni na 12 godzin (rys. 13).

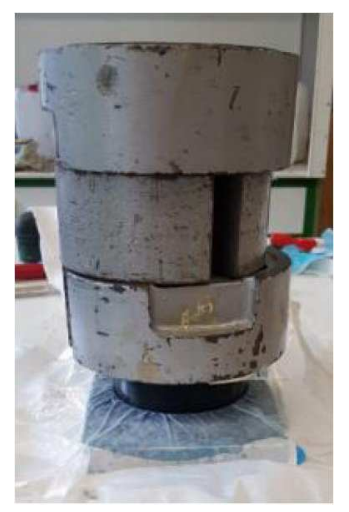

Rys. 13. Tarcza przednia w próżni

Po utwardzeniu żywicy tarcze zostały poddane obróbce (rys. 14a). Nadmiary materiału odcięto nożykiem i zeszlifowano papierem ściernym jeszcze przed odformowaniem, używając formy jako poziomu. Następnie, tak jak przewidziano w fazie projektu, rozdzielono formy na dwie części i wówczas wyjęcie gotowego elementu nie stanowiło problemu i nie wystąpiło ryzyko uszkodzenia materiału, pomimo faktu występowania ścianek równoległych do kierunku odformowania (rys. 14b).

(a)

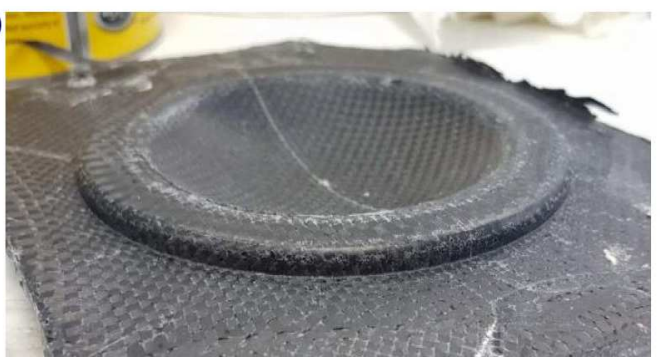

(b)

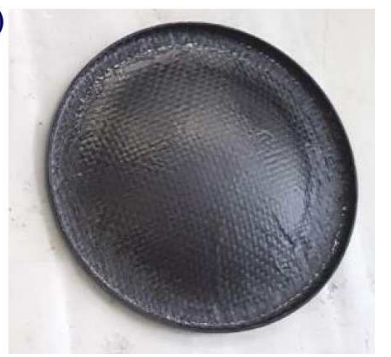

Rys. 14. (a) Próbka półfabrykatu tarczy tylnej, (b) tarcza tylna po obróbce

Według wcześniej opracowanej etapowej technologii wykonywania, poprzez zwiększanie poziomu skomplikowania wyrobu, po laminowaniu i wstępnej obróbce należało wyciąć rowki pod łopatki w tarczy przedniej wentylatora. Do tego procesu wykorzystano (opisaną w rozdziale 2.1) „koronę wzornikową” (rys. 15a). Wykorzystując wiertło $0,5 \mathrm{~mm}$, zaznaczono wstępnie tor łuku rowka, kolejno wykonano nacięcia przy użyciu piły włosowej $0,8 \mathrm{~mm}$ (rys. 15b), a następnie wykończono je pilnikiem. 
(a)

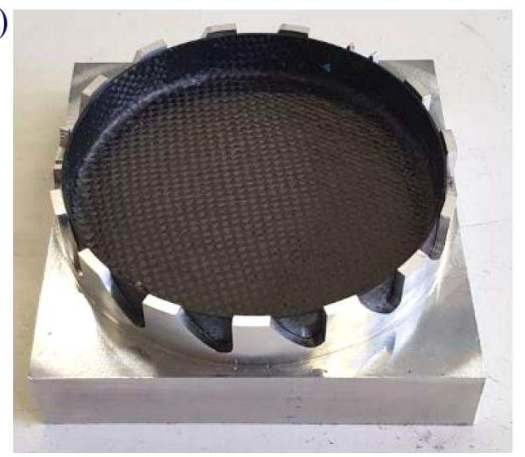

(b)

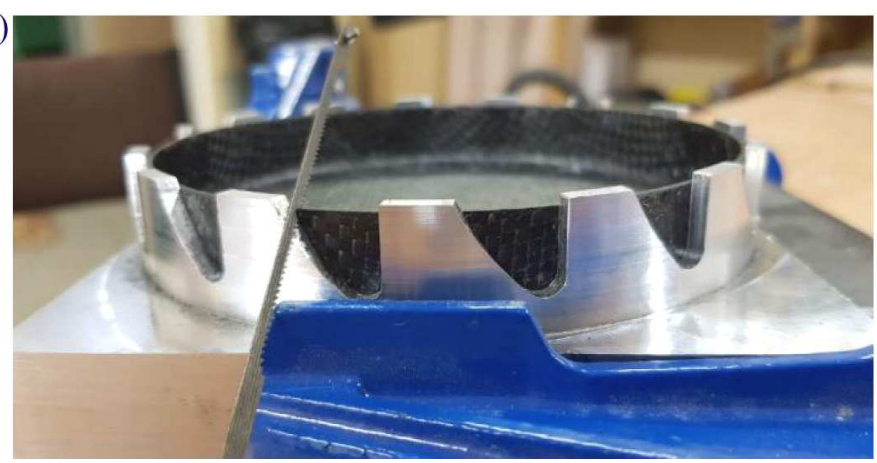

Rys. 15. (a) Tarcza przednia w koronie wzornikowej, (b) nacinanie rowków w tarczy

(a)

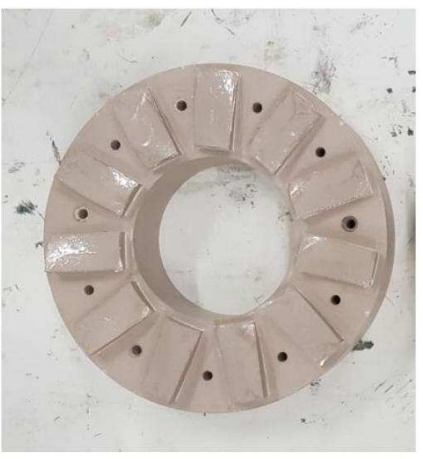

(b)

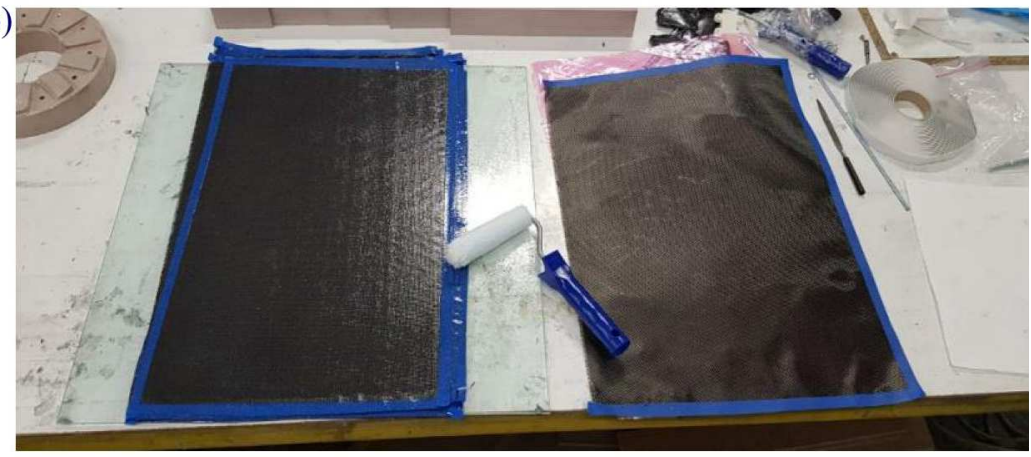

(c)

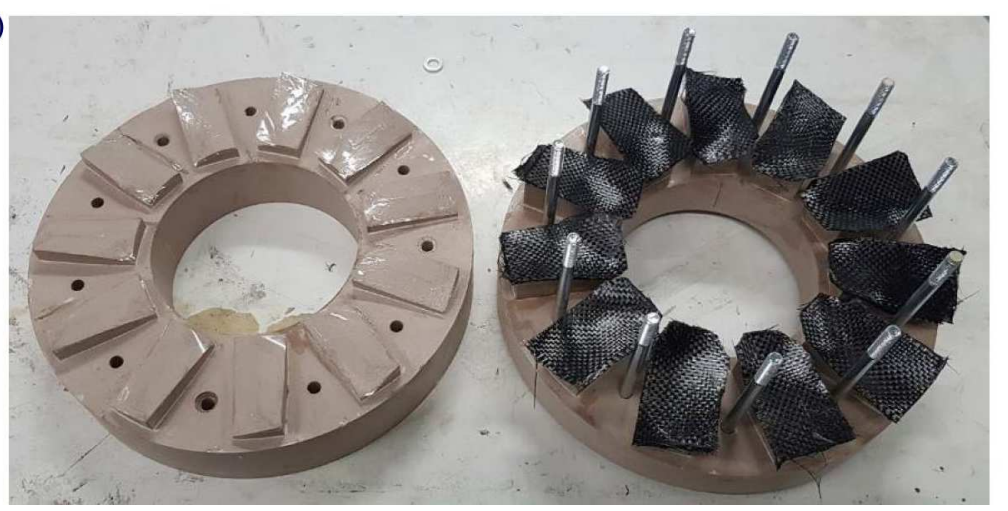

Rys. 16. (a) Przygotowana forma przed laminowaniem, (b) proces laminowania materiału węlowego, (c) układanie przelaminowanego materiału na formie

Po wykonaniu tarcz wentylatora rozpoczęto budowę łopatek. Kształt formy do wykonania łopatek uniemożliwiał wykonanie murków ochronnych zabezpieczających ostre krawędzie, a niezbędnych do uzyskania dobrej jakości powierzchni gotowego produktu. Zdecydowano się więc na rezygnację z obróbki ściernej na rzecz użycia elastycznego tworzywa sztucznego, które naklejono na powierzchnie robocze formy, uzyskując w ten sposób powierzchnię lustrzaną, gotową do laminowania (rys. 16a). Zastąpienie tradycyjnego procesu obróbki ściernej i woskowania było możliwe, ze względu na mało skomplikowaną powierzchnię łopatek (bez ostrych przejść i załamań), co w przypadku np. tarcz wentylatora nie byłoby możliwe do wykonania. Materiał węglowy laminowano w postaci dużych płacht (rys. 16b) kolejnych warstw materiału, następnie wycinano z nich, przy użyciu przygotowanego wcześniej wzornika, mniejsze fragmenty o wielkości powierzchni łopatki z niewielkim naddatkiem technologicznym. Gotowe wycinki układano na formie (rys. 16c). 
Za pomocą śrub zamknięto i dociśnięto formę z wcześniej wyznaczoną doświadczalnie siłą potrzebną do uzyskania pożądanej grubości łopatek, wynoszącej $0,8 \mathrm{~mm}$, używając wkrętarki na takiej samej nastawie sprzęgła na całym obwodzie formy (rys. 17).

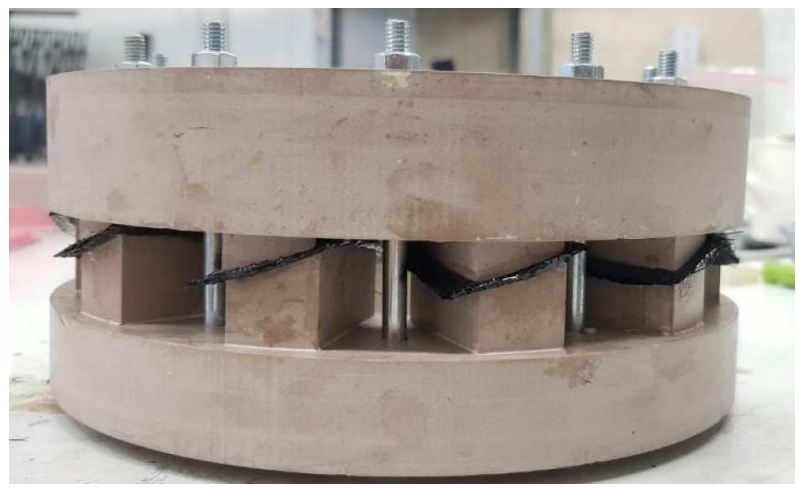

Rys. 17. Łopatki wentylatora podczas utwardzania żywicy

Po utwardzeniu żywicy i wstępnym odcięciu naddatków materiału otworzono formę. Otrzymane półfabrykaty obrobiono wstępnie na ściernicy, następnie zamontowano we wzorniku (opisanym w rozdziale 2.1) i rozpoczęto obróbkę pilnikiem (rys. 18). Do wykonania jednostopniowego zamka w półfabrykacie, posłużono się piłką i pilnikiem $0,8 \mathrm{~mm}$. Tak otrzymano gotowe łopatki (rys. 19).

(a)

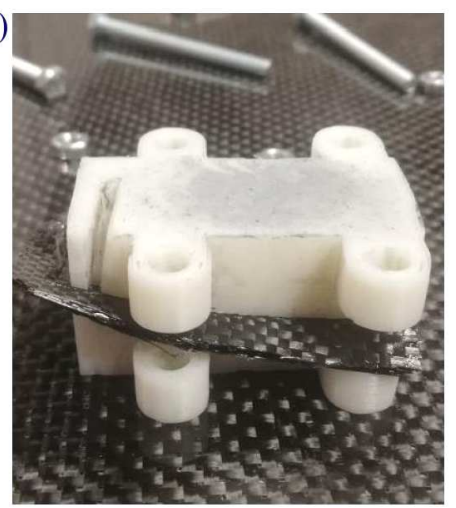

(b)

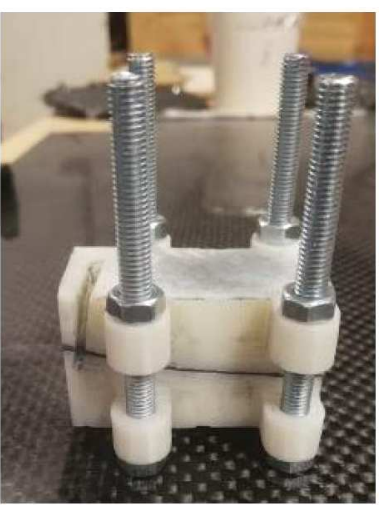

Rys. 18. (a) Półfabrykat łopatki we wzorniku, (b) łopatka po obróbce we wzorniku

(a)

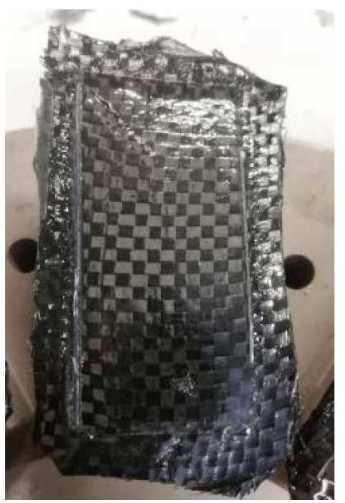

(b)

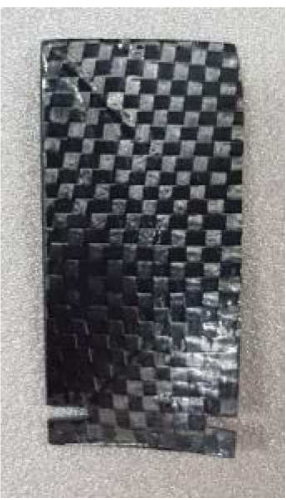

Rys. 19. (a) Półfabrykat łopatki, (b) łopatka przygotowana do montażu w tarczy 


\subsection{Montaż wentylatora}

W technologii montażu wentylatora przewidziano zastosowanie połączeń klejonych, jednak ich zadaniem, ze względu na konstrukcję wirnika, nie jest przenoszenie głównych obciążeń, lecz pełnią one rolę bardziej zabezpieczającą. Już przy próbnym montażu suchym (rys. 20a) (wykonanym bez nakładania kleju w celu sprawdzenia zgodności zamka łopatki z elementami montażowymi tarcz) wentylator, ze względu na wysoką jakość obróbki, zachowywał integralność. Sam fakt użycia śruby mocującej wirnik do silnika i ściskającej elementy tarczowe w praktyce wystarczyłby do zachowania trwałości konstrukcji. Taka zaleta wybranej metody podziału elementów składowych i zastosowanej obróbki jest niezwykle istotna z uwagi na fakt, iż konstrukcje kompozytowe charakteryzują się występowaniem stosunkowo dużych odkształceń doprowadzających do wykruszania się kleju ze spoin.

Jako klej zastosowano żywicę L285 z utwardzaczem H287 (taki sam zestaw, jak do laminowania), ale wypełnioną aerosilem w proporcjach umożliwiających otrzymanie gęstej struktury żelowatej. Zmatowiono dolne części zamków łopatek i wewnętrzne powierzchnie elementów łącznikowych tarcz w celu zapewnienia możliwie najlepszego styku kleju z kompozytem. Następnie używając sprawdzianu montażowego, nałożono łopatki do tarczy przedniej. Kolejnym etapem w procesie montażu wentylatora było naniesienie wcześniej wspomnianej cienkiej, zabezpieczającej warstwy żywicy z aerosilem (rys. 20b). Potem nałożono warstwę kleju na brzeg tarczy przedniej (rys. 20c), montując na nią tarczę tylną i ostatecznie zamykając konstrukcję wentylatora. Elementy obciążono trzy kilogramowym ciężarkiem i pozostawiono na 12 godzin do utwardzenia żywicy (rys. 20d). Po zakończonym procesie montażu nie stwierdzono żadnych wad czy skaz konstrukcji, kwalifikując ją jako gotową do umieszczenia w zespole systemu chodzącego (rys. 21).

(a)

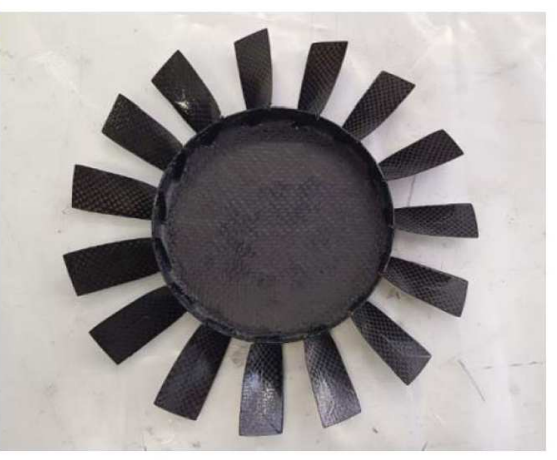

(b)

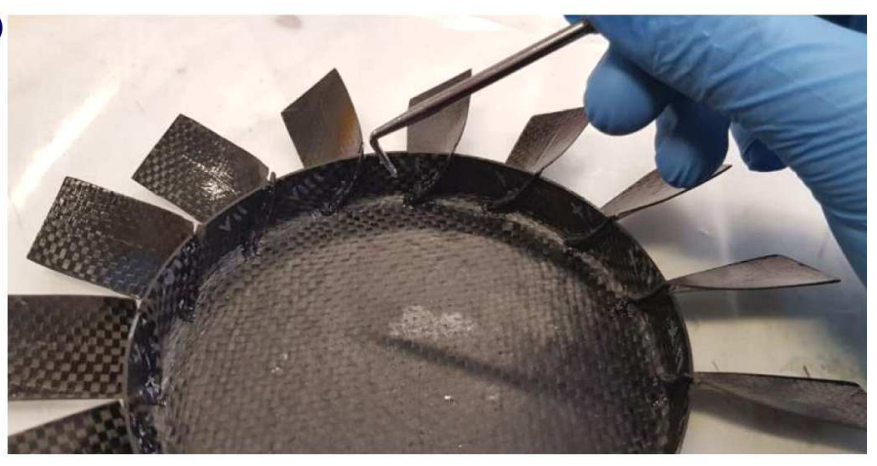

(d)

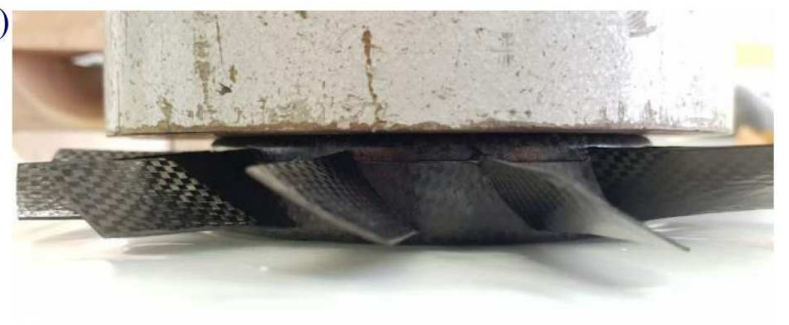

Rys. 20. (a) Montaż suchy, (b) nakładanie żywicy z aerosilem, (c) niewielka warstwa żywicy,

(d) utwardzanie żywicy

\subsection{Budowa kołpaka}

Kołpak wykonany został z tkaniny węglowej typu twill o gramaturze $200 \mathrm{~g} / \mathrm{m}^{2}$. Jak wspomniano wcześniej (rozdział 2.2), element produkowano na formie dzielonej. Dwie warstwy przelaminowanego materiału ułożono względem siebie pod kątem $45^{\circ}$ oraz tak, by zewnętrzna warstwa 


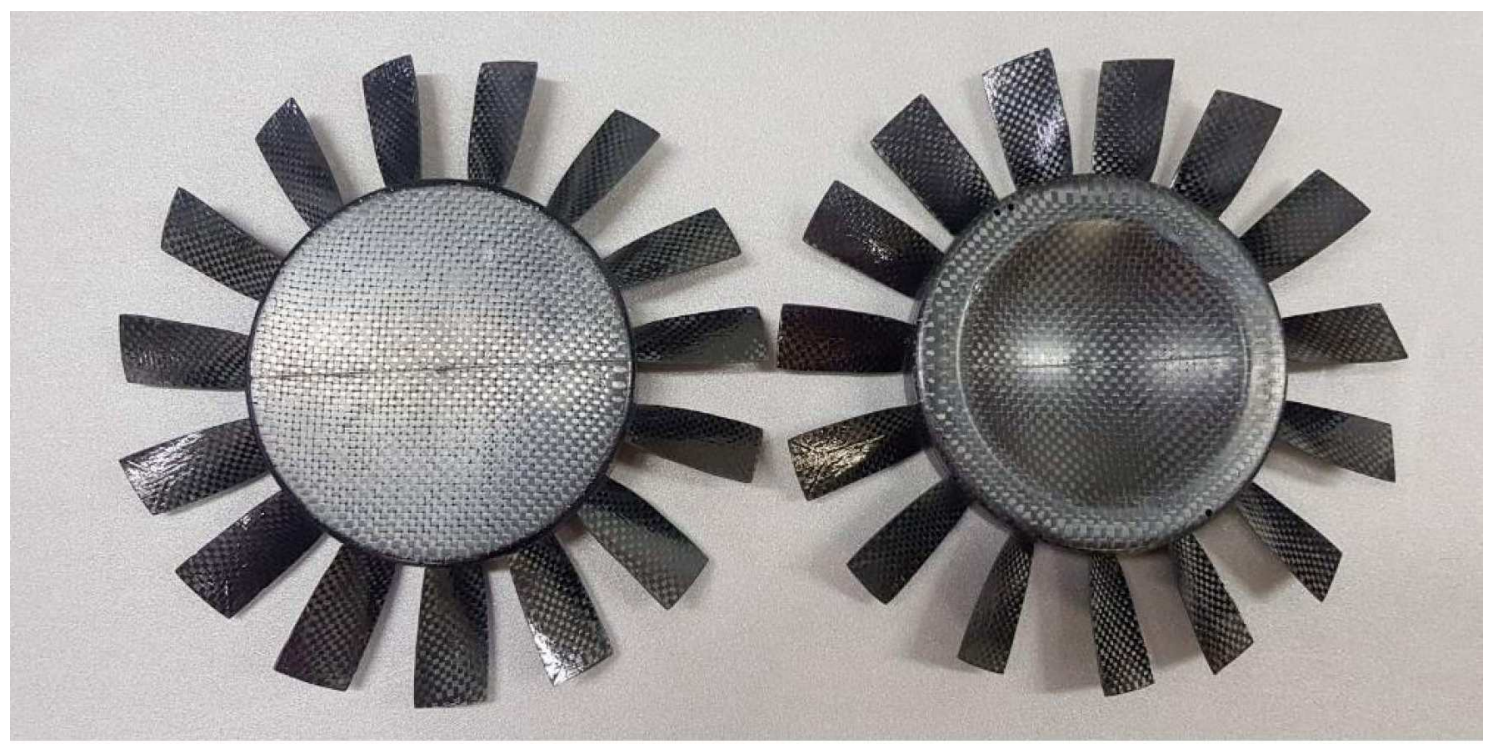

Rys. 21. Gotowe wentylatory

gotowego elementu miała spiralne ułożenie włókien, konieczne do uzyskania ze względu na stan obciążenia. Po standardowym czasie 12 godzin utwardzania żywicy elementy obrobiono, nie wyciągając ich wcześniej z formy. Następnie na wykończone krawędzie nałożono żywicę z aerosilem i wykorzystując zaplanowane wcześniej otwory w formach, połączono dwie połówki za pomocą śrub i ścisków. W kolejnym kroku spoinę wzmocniono dwoma paskami tkaniny typu textreme ciętymi diagonalnie (rys. 22a) tak, aby struktura spoiny była najkorzystniejsza względem działającego na nią rozkładu sił. Po kolejnych 12 godzinach utwardzania żywicy element odformowano i wypolerowano w celu zmniejszenia chropowatości i uzyskania lepszego efektu aerodynamicznego (rys. 22b).

(a)

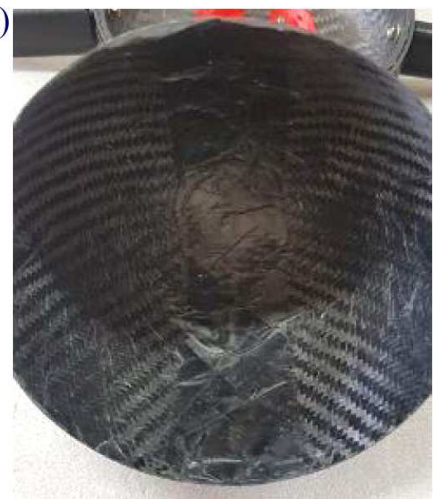

(b)

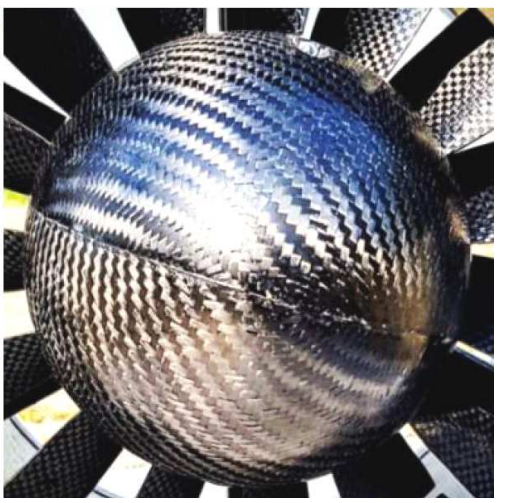

Rys. 22. (a) Półfabrykat kołpaka, (b) gotowy kołpak zamontowany na zespole chłodzącym

\section{Podsumowanie i wnioski}

W artykule przedstawiono $\mathrm{w}$ większości oryginalne i kompleksowe rozwiązania sprawiające, że technologia kompozytowa może być używana do budowy wysokoobrotowych wentylatorów chłodzących o niewielkich wymiarach średnicowych bez potrzeby przygotowania specjalnego zaplecza materiałowego, lecz przy użyciu ogólno dostępnych środków. Niektóre autorskie rozwiązania, chociażby jak podział form elementów tarczowych w płaszczyźnie pokrywającej się z osią obrotu, sprawiają, że swego rodzaju klasyczne ograniczenia konstrukcyjne, jak ścianki elementów 
niemogące być równoległe z kierunkiem odformowania, nie są już aktualne. Wbrew powszechnemu przekonaniu, co do możliwości wykonania kompozytowego wentylatora o dużej złożoności geometrycznej i niewielkich wymiarach, udało się opracować kompleksowy proces technologiczny sprawdzony i zweryfikowany w praktyce. Co bardzo istotne z punktu widzenia rozwoju i konieczności dążenia do ciągłej poprawy osiągów maszyn latających, opracowana technologia umożliwia znaczną redukcję masy elementów wyposażenia samolotu, tym samym uzasadniając użycie kompozytu jako materiału wykonawczego do budowy zespołów chłodzących.

Podsumowując, warto dodać, że projekt i wykonanie wentylatora jest jedynie częścią drogi prowadzącej do stworzenia systemu chłodzącego jako całości, czyli kompletnej kompozytowej turbiny chłodzącej (rys. 23a,b), w której skład wchodzi jeszcze potrzeba zaprojektowania wykonalnej konstrukcji statorów, zapewnienia chłodzenia silników zasilających wentylatory czy wykonanie korpusu odpornego na ewentualną dezintegrację rdzenia (rys. 23c), jednak ze względów na ograniczenia objętościowe samego artykułu będą to zagadnienia poruszane w innych publikacjach.

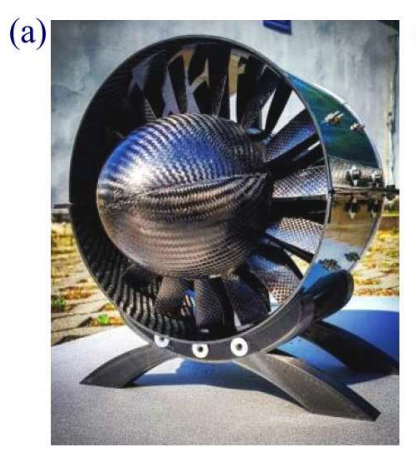

Rys. 23. (a) Zespół chodzący - widok A, (b) zespół chłodzący - widok B, (c) rdzeń zespołu chłodzącego

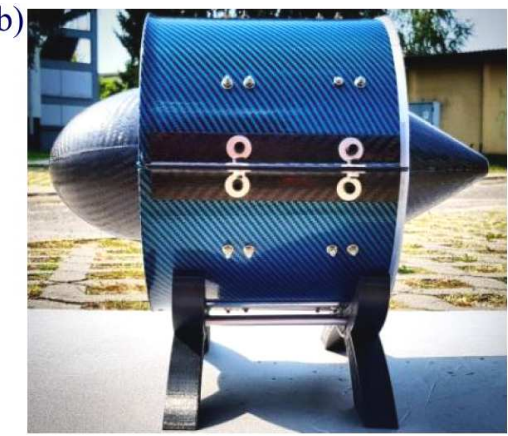

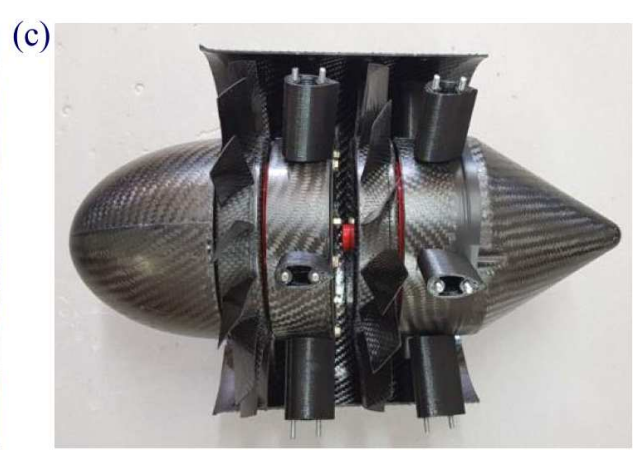

\section{Bibliografia}

1. Kaczorowska Katarzyna, Jakubowski Michae, Praca dyplomowa: Projekt $i$ wykonanie kompozytowego wentylatora chłodzacego ogniwo paliwowe motoszybowca AOS-H2, 2020

\section{Design and manufacturing technology of composite components with complex geometry for high speed applications}

This paper presents the problem of designing and developing a technology of manufacturing composite components with complex geometry for applications in high-speed equipment on the basis of AOS-H2 motor glider fuel cell cooling unit. In order to justify the use of carbon and glass laminate in this type of structure (considering relatively small maximum diameter dimensions of the assembly of $200 \mathrm{~mm}$ ), special techniques of working with the composite material are described as well as the universal design of the fan itself as a high-speed element. Its construction is divided into parts that can be made in a composite technology in a relatively short time and at a low cost while maintaining low weight and reliability of the final product. The article, among other things, presents the way of designing moulds in the ProLab material of low density with the use of "protective walls", on the edges exposed to damage during processing to improve the quality of the surface. It discussed division of the edges in the plane parallel to the direction of demoulding, a complex scheme of processing carbon blades with the use of tools made by $3 \mathrm{D}$ printing and the technology of assembly of individual components. Thanks to the original design and manufacturing techniques, the quality of the final product justifies the use of composite materials in small high-speed structures. 